\title{
PRODUCTION OF BIODIESEL FROM MARINE MACROALGAE OCCURRING IN THE GULF OF GUINEA, OFF THE COAST OF GHANA
}

\author{
G. K. AmekA*, L. K. Doamekpor, A. A. Amadu And A. P. Amamoo \\ (G. K. A. \& A. A. P.: Department of Plant and Environmental Biology, University of Ghana, $P$. \\ O. Box LG 55, Legon, Accra, Ghana; L. K. D.: Department of Chemistry, University of Ghana, \\ P. O. Box LG 56, Legon, Accra, Ghana; A. A. A.: CSIR - Water Research Institute, P. O. Box \\ AH 38, Achimota, Accra, Ghana). \\ *Corresponding author's e-mail: gameka@ug.edu.gh
}

\begin{abstract}
The purpose of this study was to determine the suitability of marine macroalgae (also known as seaweeds), from the Gulf of Guinea, off the coast of Ghana, for the production of biodiesel as an alternative to liquid fuels like gasoil and gasoline. Five green marine macroalgae species: Caulerpa taxifolia, Chaetomorpha antennina, Chaetomorpha linum, Ulva fasciata, and Ulva flexuosa, were collected from the coastal waters of Ghana at West Tema Rocks during low tide. Algal lipids were extracted from dried algae biomass with hexane and diethyl ether. Biodiesel was produced from algal lipids by base-catalysed transesterification, with alcohol. The lipid content of samples was highest in C. linum (1.13 g; 5.65\% dry wt.) and lowest in C. antennina $(0.54 \mathrm{~g} ; 2.70 \%$ dry wt.). Similarly, the quantity of biodiesel produced from the lipids was highest in $C$. linum $(0.97 \mathrm{~g} ; 4.85 \%$ dry wt.) and lowest in $C$. antennina $(0.48 \mathrm{~g} ; 2.40 \%$ dry wt.). The quantity of biodiesel produced from samples of the five species fell well within the range obtained for such species worldwide. The implications of the yield of biodiesel for commercial production and future work on marine macroalgae from Ghana as source of biofuel are discussed.
\end{abstract}

Keywords: Marine macroalgae, Ulvophyceae, algal lipids, transesterification, biodiesel.

\section{Introduction}

The increasing global population and the desire for greater economic growth have resulted in an ever increasing demand for energy worldwide (Afify et al., 2010). The growth in demand for energy, over the last few decades, is so great that it is almost suicidal for humanity to continue to rely on a limited range of energy sources. The main sources of energy available now are: hydropower, wind, and solar, which are renewable; and nuclear, and fossil fuels such as natural gas, coal, gasoline and gasoil, which are non-renewable. Currently, a large proportion of the world's energy requirements are met by depending on non-renewable energy derived from fossil fuels. The other energy sources: hydropower, solar, and wind (which are renewable), at present contribute very little to the global energy requirements. Additionally, according to Campbell (2008) the world had entered into a period of declining non-renewable energy resources (fossil fuels) 
popularly known as 'Peak Oil', while energy demands are increasing. Moreover, the world's crude oil production is expected to decline rapidly in about ten decades (Crookes, 2006). Bearing in mind that crude oil is a fossil fuel and, therefore, not renewable within a human life span, its supply will eventually deplete considering the rate at which it is currently extracted and utilised.

Our reliance on fossil fuels does not only lead to the gradual depletion of the resource, but also results in environmental pollution, particularly the production of greenhouse gases e.g., carbon dioxide and oxides of nitrogen, and aggravates the greenhouse effect (Sharif et al., 2008); leading to climate change and the concomitant challenges including global temperature rise, sea level rise, and biodiversity loss. There is, therefore, the need to increase the contribution of existing renewable sources of energy, and also seek other alternative sources of fuel which are renewable and contribute less to the greenhouse effect. The need for renewable sources of portable, liquid fuel has started to receive greater attention and much of this attention has been focused on biomass derived liquid fuels or biofuels (Campbell, 2008).

Biomass is a better source of energy since biomass energy is sustainable and environmentally friendly. Biodiesel is biomass energy, derived from vegetable oil or animal fat (Maceiras et al., 2011); which is biodegradable, nontoxic and has a low emission profile (Demirbas, 2009; Maceiras et al., 2011). The production of biodiesel, or alkyl esters, is well known. There are three basic routes to ester production from oils and fats: (i) base-catalyzed transesterification of the oil with alcohol, (ii) direct acid-catalyzed esterification of the oil with methanol, and (iii) conversion of the oil to fatty acids, and then to alkyl esters with acid catalysis. The majority of the alkyl esters produced today are done with the base-catalyzed reaction because it is the most economic (Raghuveer et al., 2015). Suganya et al. (2013) further reported that, base-catalysed reactions are the highest yielding.

Among biomass energy sources, algae represent a better source of biodiesel, as they do not compete with the existing cereal and oilseed markets. Algae unlike terrestrial crops, do not require agricultural land for cultivation, many species grow in freshwater, thus avoiding competition for land (Chisti, 2007; Milledge et al., 2014). According to Walker (2009), Trediei (2010), and Williams \& Laurens (2010) the yield of algae per unit area is usually higher than that of terrestrial plants. Studies by Rajkumar et al., (2013) and Leu \& Boussiba (2014) indicated that brown marine macroalgae, for example, gave yields of about $13 \mathrm{~kg}$ dry wt. $\mathrm{m}^{-2} \mathrm{yr}^{-1}$ compared to sugar cane with about $10 \mathrm{~kg}$ dry wt. $\mathrm{m}^{-2} \mathrm{yr}$ 1. Thus algae have a high photosynthetic efficiency and biomass production, faster growth rate, high carbon dioxide fixation and oxygen production than other crops (Chisti, 2007). Organelles within the algal cell are thought to be responsible for these properties. Some of these organelles such as pyrenoids are frequently associated with storage products (Lee, 2008).

According to Sharif et al. (2008) marine macroalgae, also known as seaweeds, and microalgae can provide different types of renewable biofuels. The renewable biofuels include: methane produced by anaerobic digestion of algal biomass; biodiesel derived from algal oil; and photo-biologically produced bio-hydrogen. Similarly, McHugh (2003) reported that some three decades ago projects that investigated possible use of seaweeds as an indirect source of fuel were initiated. The 
idea was to grow large quantities of seaweed in the ocean and then ferment this biomass to generate methane gas for use as a fuel. Projects to produce biodiesel from macro- and micro-algae are progressing steadily in many parts of the world; for instance, in North and South America, Europe, Asia and Australia (Demirbas, 2009; Chisti, 2010). However, very little work is going on in sub-Saharan Africa, and in particular, the West Africa Subregion.

There is paucity of information regarding the types of marine macroalgae that are suitable, and could yield high quantities of oil for biodiesel production or other useful products in the West African Sub-region. This study was, therefore, initiated to verify whether green macroalgae in the Gulf of Guinea, off the coast of Ghana could yield oil for biodiesel production.

\section{Experimental}

Five green marine macroalgae (Phylum: Chlorophyta, Family: Ulvophyceae) namely: Caulerpa taxifolia (Vahl) C. Agardh, Chaetomorpha antennina (Bory) Kützing, Chaetomorpha linum (O. F. Müller) Kützing, Ulva fasciata Delile, and Ulva flexuosa (Wulfen ex Roth) J. Agardh, were collected from the Gulf of Guinea, off the coast of Ghana, at the West Tema Rocks, located at longitude $5^{0} 36.822^{\prime} \mathrm{N}$, and latitude $000^{\circ} 01.723^{\prime} \mathrm{W}$ (Fig. 1), $\pm 10 \mathrm{~m}$ alt., at low tide in September 2016.

Samples of the five marine macroalgae were removed from their substrates with either a scalpel or by hand, and rinsed in sea water to remove adherent debris such as shells, sand, mud; and epiphytes were removed by scraping them off gently with tissue paper. The macroalgae samples were transported to the laboratory within $1 \frac{1}{2}$ hours, rinsed in tap water to remove salt and any remaining adhering debris (Istini et al., 1994), and dabbed dry with a dry cloth. The fresh and dry weights of the macroalgae samples were measured by weighing $200 \mathrm{~g}$ fresh weight of each species in triplicate, using a Mettler top loading balance. The $200 \mathrm{~g}$ wet samples of each species were dried in a Gallenkamp hot-air circulating oven at $60^{\circ} \mathrm{C}$ until constant dry weights were achieved within 48 hours. An Adam ABC plus 300 weighing balance was used to determine the dry weight of the samples. The fresh and dry weights obtained were used to determine the water and dry matter content of each species. The dried samples were ground into a fine powder, with a Kenwood miller to pass through a $2 \mathrm{~mm}$ sieve. 


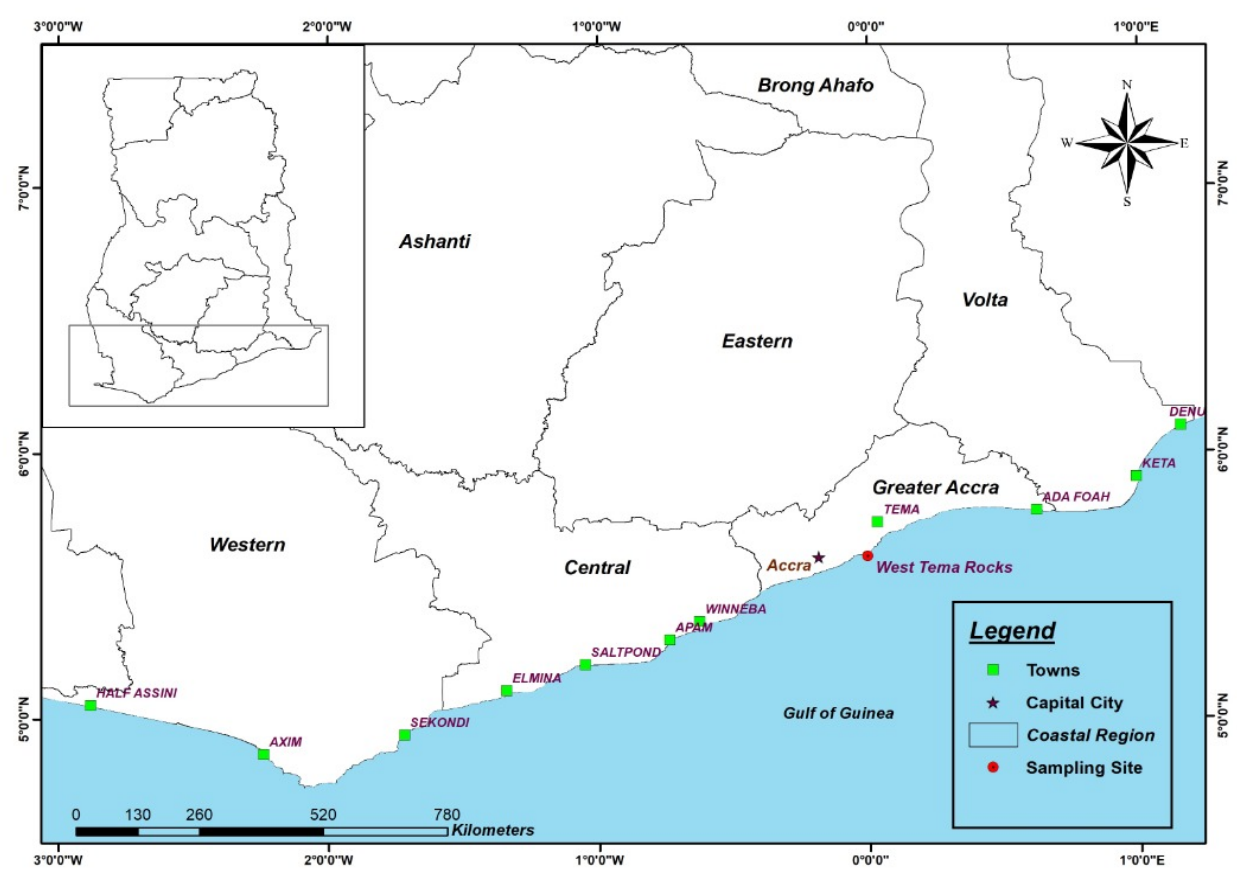

Fig. 1: Map of Ghana showing sampling location.

Algal oil was extracted from dried samples of the five green marine macroalgae. The extraction of lipids from algal biomass and their transesterification to produce biodiesel followed closely the procedure by Vicente et al. (2004) Demirbas (2009), and Raghuveer et al. (2015). A $20 \mathrm{~g}$ algae powder, of each species in triplicate, was weighed into $500 \mathrm{ml}$ conical flask, and mixed with $200 \mathrm{ml}$ of hexane and $100 \mathrm{ml}$ of diethyl ether solution. The mixture was stirred for 24 hours on a magnetic stirrer in a fume cupboard. The mixture was filtered using a fluted filter paper into a round bottomed flask and the solvents were evaporated off using a Cole-Palmer Rotary Evaporator. Transesterification was achieved by base catalysis following the procedure by Demirbas (2009), and Raghuveer et al. (2015). One gram of sodium hydroxide $(\mathrm{NaOH})$ was mixed with $30 \mathrm{ml}$ methanol. This mixture was then added to the algae extract and stirred for 24 hours on a magnetic stirrer. The mixture was transferred into a separating funnel and the immiscible layers were left to settle for 24 hours. The mixture separated into two layers; organic and aqueous layer. The sediment (glycerol and algal pigments) were recovered separately following Sharif et al. (2008). The organic layer was washed with water to purify it, and was subsequently dried with sodium sulphate $\left(\mathrm{Na}_{2} \mathrm{SO}_{4}\right)$ and anhydrous magnesium sulphate $\left(\mathrm{MgSO}_{4}\right)$ to remove as much water as possible. The organic layer (biodiesel) was transferred into a round bottomed flask and the solvents were evaporated by a Cole-Palmer Rotary Evaporator. The amount of biodiesel produced was weighed and the $\mathrm{pH}$ determined. The data obtained was analysed statistically to 
compare the means of the different parameters (lipid content, sediment fraction, biodiesel content, and $\mathrm{pH}$ of biodiesel) using one-way analysis of variance (ANOVA). Normality of the data were assessed using the Shapiro-Wilk normality test before ANOVA. Where the data were not normally distributed, they were log-transformed to achieve normality. Data analyses were carried out using $\mathrm{R}$ statistical package (www.r.org). Statistical significance was reported at $p$-value of $\leq 0.05$.

\section{Results and Discussion}

Among the five green marine macroalgae: Caulerpa taxifolia, Chaetomorpha antennina, Chaetomorpha linum, Ulva fasciata, and Ulva flexuosa studied, C. taxifolia (15\%) had the highest percent dry weight value while $U$. fasciata (9\%) had the lowest value (Table 1). The results indicated that $C$. taxifolia had more dry matter than the other species. The water content of all the species ranged from $85-90 \%$. This fell well within the range, 80 - $90 \%$, reported for marine macroalgae by Milledge et al. (2014).

TABLE 1

Fresh and dry weights of marine macroalgae from West Tema Rocks, Ghana.

[wt. - weight; SE-Standard error].

\begin{tabular}{lllc}
\hline Alga species & $\begin{array}{l}\text { Fresh wt. } \\
(\mathrm{g})\end{array}$ & $\begin{array}{l}\text { Dry wt. } \pm \text { SE } \\
(\mathrm{g})\end{array}$ & $\begin{array}{l}\text { \% Dry wt. } \pm \text { SE } \\
(\mathrm{g})\end{array}$ \\
\hline Caulerpa taxifolia & 200.00 & $28.89 \pm 1.02$ & $14.44 \pm 0.99$ \\
Chaetomorpha antennina & 200.00 & $20.58 \pm 2.10$ & $10.29 \pm 1.88$ \\
Chaetomorpha linum & 200.00 & $18.02 \pm 1.74$ & $9.01 \pm 1.82$ \\
Ulva fasciata & 200.00 & $17.76 \pm 0.98$ & $8.88 \pm 0.96$ \\
Ulva flexuosa & 200.00 & $19.44 \pm 1.09$ & $9.72 \pm 0.98$ \\
\hline
\end{tabular}

Our results showed that the five green marine macroalgae contained lipids, pigments, and other algae biomass. Algal lipids usually contain triglycerides which during esterification are converted to methyl esters (biodiesel) and glycerol (Ahmed et al., 2010). The lipid content of the dried marine macroalgae species in this study was highest in C. linum (1.13 g; 5.65\% dry wt.) and lowest in C. antennina (0.54 g; $2.70 \%$ dry wt.) (Figs. $2 \& 3)$. The differences between the lipid (g) contents of the species were significant $(\mathrm{p} \leq$ $\left.1.21 \times 10^{-8}\right)$. Also the lipid content on percent dry weight basis varied significantly ( $\mathrm{p} \leq$ $2.44 \times 10^{-8}$ ) among the macroalgae species assessed. The differences in lipid content of algal species, according to Napan et al., (2015) could be attributed to the inherent lipid accumulation capacities of the different species. Also when algae species are starved, that is, deprived of nitrogen, the amount of oil produced increases (Napan et al., 2015).

Similarly quantities of biodiesel produced (Figs. 4 \& 5) were highest in $C$. linum $(0.96 \mathrm{~g}$; $4.85 \%$ dry wt.) and lowest in C. antennina $(0.48$ 
g; $2.40 \%$ dry wt.). The biodiesel (g) yield of the macroalgae species studied varied, and the differences in yield were significant $(\mathrm{p} \leq 5.05$ $\left.\mathrm{x} 10^{-9}\right)$. Likewise, the differences in yield of biodiesel on dry weight basis from the samples of the species were significantly different ( $p$ $\left.\leq 1.26 \times 10^{-6}\right)$. Although $C$. taxifolia had the highest dry matter (Table 1 ) it did not produce the highest lipid content (Fig. 2). Perhaps due to presence of higher lignocellulose content which contributed the dry matter.

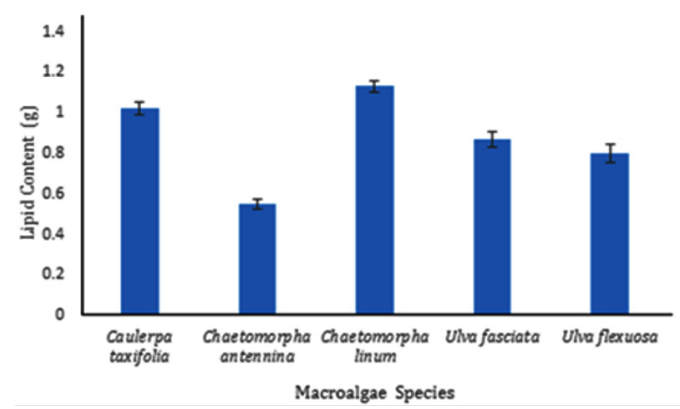

Fig. 2: Lipid content ( $\mathrm{g}$ ) of samples of five marine macroalgae species from West Tema Rocks in the Gulf of Guinea, off the coast of Ghana. Error bar: Mean \pm standard error.

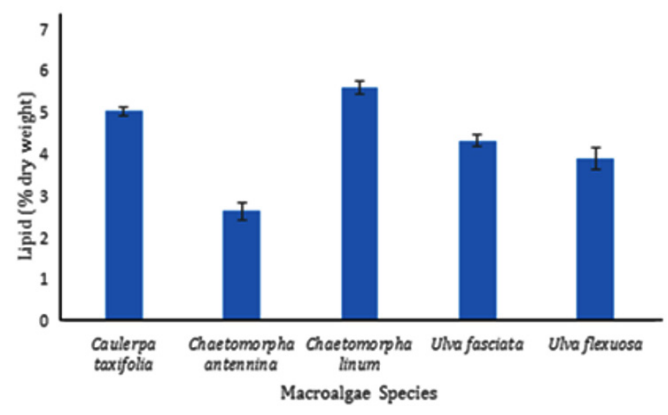

Fig. 3: Lipid content (\% dry wt.) of samples of five macroalgae species from West Tema Rocks in the Gulf of Guinea, off the coast of Ghana. Error bar: Mean \pm standard error.
Previous authors have reported on quantities of lipid found in marine macroalgae, e.g., Aresta et al. (2005) for Chaetomorpha linum, Suganya et al. (2013) for Ulva compressa, Suganya \& Renganathan (2012) for Ulva lactuca. Research done by these authors showed that the lipid content from these macroalgae did not exceed $11.00 \%$ dry wt. Ahmed et al. (2010), for example, found that the lipid content was $8.87 \%$ and $2.48 \%$ dry wt. for Gracilaria and Cladophora species, respectively. According to Sumithrabai et al. (2011) the lipid content of marine macroalgae vary from $1.30-7.80 \%$ dry wt. Vincecate (2006) also reported that in general the quantity of lipid in marine macroalgae is about $5.50 \%$. The lipid content of marine macroalgae from the current study varied from 2.70 to $5.70 \%$ dry wt. and similar to those reported in earlier studies and thus confirmed the suggestion of Nelson et al. (2002) that lipid content of the macroalgae varies from species to species.

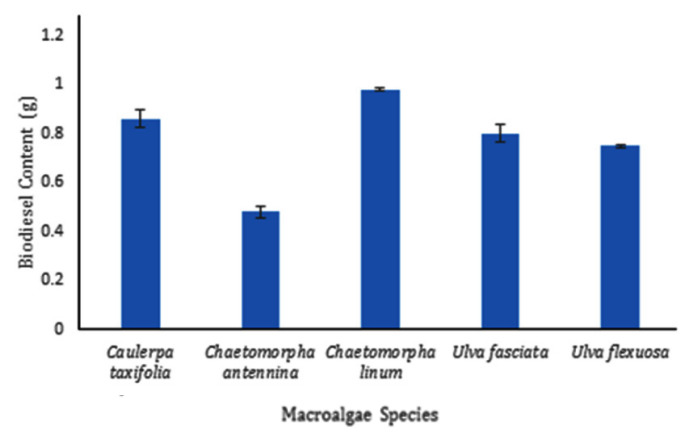

Fig. 4: Biodiesel content (g) of samples of five marine macroalgae species from West Tema Rocks, Ghana. Error bar: Mean \pm Standard error.

The sediment fraction was principally glycerol and pigments. The glycerol was produced during transesterification of algal oil. In this study the sediment fraction ranged from 0.04 
to $0.14 \%$ dry wt. (Fig. 6). Different quantities of sediment fraction were observed (Fig. 6) and the differences were significant $(\mathrm{p} \leq 1.45$ $\times 10^{-3}$ ). The glycerol and pigments could also constitute raw materials for other products.

The $\mathrm{pH}$ of biodiesel from the marine macroalgae studied ranged between 5.60 and 6.80 (Fig. 7). Acidity measured as $\mathrm{pH}$ of the five marine macroalgae species varied significantly $\left(\mathrm{p} \leq 1.28 \times 10^{-6}\right)$ among the species. According to Dunst (2016) the $\mathrm{pH}$ of petroleum diesel fuel ranges from about 5.50 to 8.00 . Below 5.50 diesel oil becomes acid and can cause corrosion of metal components of storage tanks. Thus biodiesel produced in the present study met the $\mathrm{pH}$ requirement for petroleum diesel for storage.

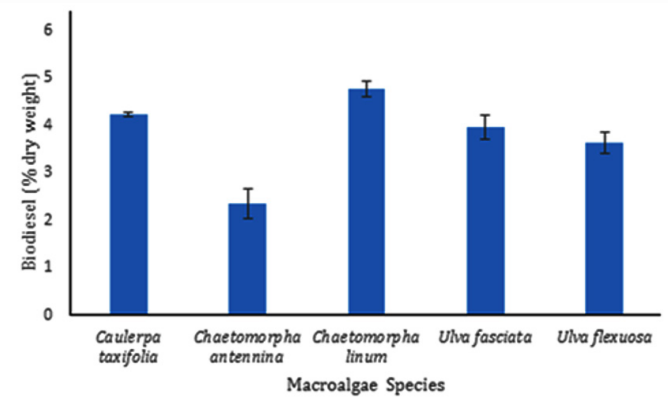

Fig. 5: Biodiesel content ( $\%$ dry wt.) of samples of five marine macroalgae speciesfrom West Tema Rocks,

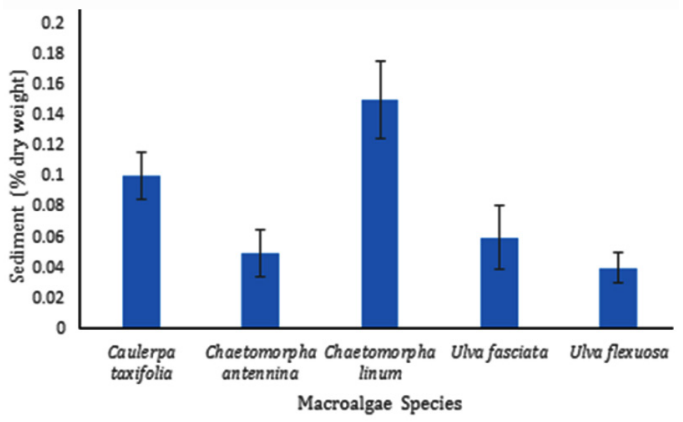

Fig. 6: Sediment fraction (\% dry wt.) of samples of five marine macroalgae species from West Tema Rocks, Ghana. Error bar: Mean \pm Standard error.

\section{Conclusion}

Results of the present study indicated that the five marine macroalgae species (Caulerpa taxifolia, Chaetomorpha antennina, Chaetomorpha linum, Ulva fasciata, and Ulva flexu$o s a$ ), occurring in the coastal waters of Ghana contained lipids which were converted into biodiesel by base-catalysed transesterification. However, the species investigated contained lipids up to a maximum of $5.70 \%$ dry weight in their thalli. The quantities of biodiesel obtained from the five species were thus very low, $4.8 \%$ dry wt., and as such large scale production of biodiesel from these species would not be commercially viable. It would, however, be relevant to evaluate the yield of biodiesel from other macroalgae - green, brown and red, to determine their possible large scale production.

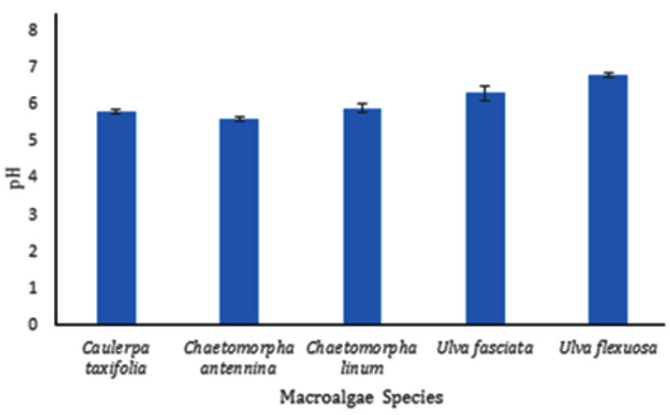

Fig. 7: $\mathrm{pH}$ of biodiesel from samples of five marine macroalgae species from West Tema Rocks, Ghana. Error bar: Mean \pm Standard error.

\section{Future Studies}

This study examined the quantities of biodiesel produced by five green marine macroalgae. The biodiesel content of the species was low, and thus not commercially viable at present. However, the $\mathrm{pH}$ of biodiesel produced compared favourably with diesel from crude 
oil. Future studies apart from determining best technology for high yield of biodiesel should also evaluate other physicochemical characteristics of the biodiesel produced such as viscosity, specific gravity, and flash point, etc. Such analyses will enable better comparison of renewable and more environmental friendly biodiesel from marine macroalgae and nonrenewable and environmentally damaging diesel from fossil fuel.

\section{References}

Afify, A. E. M. R., Shallaby, E. A. \& Shanab, M. M. (2010) Enhancement of biodiesel production from different species of algae. GRASAS $Y$ ACEITES 61 (4), 416 - 422.

Ahmed, A. S., Khan, S., Hamdan, S., et al., (2010) Biodiesel production from macroalgae as a green fuel for diesel engine. Journal of Energy \& Environment 2, 1 - 5 .

Aresta, M., Dibenedetto, A., Carone, M., et al., (2005) Production of biodiesel from macroalgae by supercritical $\mathrm{CO}_{2}$ extraction and thermochemical liquefaction. Environ. Chem. Lett. 3, 136 - 139.

Campbell, M. N. (2008) Biodiesel: Algae as a renewable source for liquid fuel. Guelph Engineering Journal, 1: 2-7.

Chisti, Y. (2007) Biodiesel from microalgae. Biotechnol. Adv., 25, 294 - 306.

Chisti, Y. (2010) Fuels from microalgae. Biofuels, 2 , $233-235$.

Crookes, R. J. (2006) Comparative bio-fuel performance in internal combustion engines. Biomass and Bioenergy_30 (5), 461 - 468.

Demirbas, A. (2009) Production of biodiesel from algae oils. Energy Sources, Part A, 31, 163 168.
Dunst, J. (2016) Fuel: how to maintain stored diesel fuel. Available online at: https://www. government-fleet.com/157049/how-tomaintain-stored-diesel-fuel.

ISTINI, S., OHNO, M. \& KUSUNOSE, H. (1994) Methods of analysis for agar, carrageenan and alginate in seaweed. Bull. Mar. Sci. Fish., Kochi Univ. 14, 49 - 55.

LeE, R. E. (2008) Phycology. $4^{\text {th }}$ Edition Cambridge, UK: Cambridge University Press.

Leu, S. \& Boussiba, S. (2014) Advances in the production of high-value products by microalgae. Ind. Biotechnol. 10, 169 - 183.

Maceiras, R., Rodriguez, M., Cancela, A., et al., (2011) Macroalgae: raw material for biodiesel production. Applied Energy 88, 3318 - 3323.

Mchugh, D. J. (2003) A guide to the seaweed industry. FAO Fisheries Technical Paper 441. FAO: Rome.

Milledge, J. J., Smith, B., Dyer, P. W., et al., (2014) Macroalgae-derived biofuel: A review of methods of energy extraction from seaweed biomass. Energies 7, $7194-7222$.

Napan, K., Christianson, T., Vole, K., et al., (2015) Quantitative assessment of microalgae biomass and lipid stability postcultivation. Front. Energy Res, 3, 15. doi: 10.3389 /fenrg.2015.00015.

Nelson, M. M., Phleger, C. E. \& Nichols, P. D. (2002) Seasonal lipid composition in macroalgae of the North-eastern Pacific Ocean. Botanica Marina 45, 58 - 65.

Raghuveer, D., Vijay, M., Sreeraulu, D., Et al., (2015) Production of biodiesel from renewable biological sources. International Conference on Biotechnology, Nanotechnology \& Environmental Engineering (ICBNE'15) April 22-23, 2015, Bangkok, Thailand. 
RAJKumar, R., YAAKob, Z. \& TAKRIFF, M. S. (2013) Potential of the micro- and macro-algae for biodiesel production. A brief review. BioResources 9, 1606 - 1633.

Sharif, A. B. M. H., Aishah, S., Nasrulhaq, A.B., et al., (2008) Biodiesel fuel production from algae as renewable energy. American Journal of Biochemistry and Biotechnology 4 (3), 250 254.

Suganya, T., Nagendra, G. N. \& Renganathan, S. (2013) Production of algal biodiesel from marine macroalgae Enteromorpha compressa by two step process: optimization and kinetic study. Bioresour Technol. 128, 392 - 400.

Suganya, T. \& Renganathan, S. (2012) Optimization and kinetic studies on algal oil extraction from marine macroalgae Ulva lactuca. Bioresour. Technol. 107, 319 - 326.

Sumithrabai, K., Thirumarimurugan, M., \& GopaLAKRISHNAN, S. (2011) Biofuel from Algae. International Journal of Advanced Engineering Technology 2 (3), 320 - 323.
TredieI, M. R. (2010) Photobiology of microalage mass cultures: understanding the tools for the next green revolution. Biofuels 1, 143 - 162.

Vincecate, G. (2006) Seaweed with more than 5.5\% oil. Sci. Biology. Available online at: http:// floatingislands.com/seaweed-oil/.

Vicente, G., Martinez, M., \& Aracil, J. (2004) Integrated biodiesel production: a comparison of different homogeneous catalysts systems. Bioresource Technology 92 , $297-305$.

WaLKer, D. (2009). Biofuels, facts, fantasy, and feasibility. J. Appl. Phycol. 21, 509 - 517.

Williams, P. J. L. B. \& Laurens, L. M. L. (2010) Microalgae as biodiesel and biomass feed stocks: Review and analysis of the biochemistry, energetics and economics. Energy Environ. Sci. 3, 554 - 590 .

Received 03 Oct 18; revised 06 Aug 19 